\title{
Socialização / Socialization
}

https://doi.org/10.21814/uminho.ed.36.56

\section{Pascale Garnier}

Université Sorbonne Paris Nord, France 



\section{Socialização}

A socialização é um conceito-chave na Sociologia da Infância e, de forma mais ampla, uma pedra angular da Sociologia desde o seu início. O conceito tem uma longa história, com muitas conceções teóricas diferentes do que significa ser "social". Existem tantas definições que é impossível abordá-las todas aqui. Entre elas, este artigo concentrar-se-á em duas visões concorrentes do processo de socialização. A primeira, a chamada visão "clássica", pode ser remetida para as ideias de Émile Durkheim, um dos fundadores das ciências sociais modernas. A outra é baseada na conceção recente de William Corsaro de socialização como a reprodução interpretativa das crianças dos mundos dos adultos. Analisaremos como esse conflito de visões se baseia na questão das representações da diferença e da igualdade entre adultos e crianças. Traz também à luz a importância de estudar as classificações em função da idade subjacentes às teorias sociológicas de socialização.

Na visão de Durkheim, a socialização das crianças é, em primeiro lugar, uma questão de autoridade: "a natureza do homem não pode ser ela mesma a menos que seja disciplinada” (Durkheim, 1972, p. 111). A socialização, então, significa tornar-se plenamente humano, a partir da sua integração numa sociedade e, mais precisamente, tornando-se parte da divisão do trabalho que caracteriza essa sociedade. Ser socializado é também uma condição para se tornar um eu autêntico, uma pessoa singular. O processo de se tornar parte de uma sociedade requer a integração das regras morais que os seus membros já partilham. A socialização é, portanto, um processo vertical de transmissão cultural, de uma geração antiga para a nova. Nesta conceção o importante é o devir das crianças, processo que se inicia na vida familiar e depois avança na escolaridade, que melhora a homogeneidade do comportamento moral e o sentimento de cidadania nacional, posteriormente conquistado no mundo do trabalho. Nessa conceção tradicional de socialização, as crianças são consideradas membros da vida social e não, ainda, membros plenos. Na visão de Durkheim, as crianças têm interesse em crescer, imitando os adultos para ganhar estatuto de prestígio em vez de serem apenas dominadas. Os adultos parecem ser tão poderosos que Durkheim alerta para não confundirem abuso de poder ou violência e autoridade legítima que a sociedade thes delegou sobre as crianças. 
Hoje, mesmo que divirjam da teoria social de Durkheim, muitos sociólogos apoiam-se num tipo de ontologia de estrutura social que as crianças precisam internalizar. Dependendo da investigação, os grupos sociais pré-existentes podem ser diferentes em termos de género, classes sociais, grupos profissionais ou de lazer, etc. Mas em cada caso, a socialização significa estar, em primeiro lugar, fora desses grupos e integrar progressivamente os valores, as normas, os princípios de perceção e ação que são compartilhados pelos seus membros como formas "naturais" de ser e se comportar. A socialização é, assim, naturalizada nos corpos das crianças.

Por outro lado, a conceção de socialização de Corsaro baseia-se na importância das interações entre as crianças e na importância das culturas locais dos pares. Esta conceção enfatiza "o desejo das crianças de alcançar autonomia das regras e autoridade dos cuidadores adultos e obter controlo sobre as suas vidas" (Corsaro 2011, p. 166), mesmo que ainda sejam afetadas por adultos. $O$ estudo da participação social de crianças pequenas em grupos de pares não mostra apenas cooperação, mas também conflitos e diferenciação social. As crianças são consideradas não como seres futuros, que estarão envolvidos na vida social, mas desde o seu nascimento como atores sociais no seu quotidiano. Nesta perspetiva, a socialização das crianças não é definida como uma reprodução do mundo dos adultos, onde são "moldadas e guiadas por forças externas" (Corsaro 2011, p. 375). Ao contrário, a socialização requer competências interpretativas, modos próprios de dar sentido às suas vidas. Esta conceção abre espaço para a agência infantil e lança luz sobre as dimensões inovadoras e criativas da sua vida social.

De Durkheim, um sociólogo francês que trabalhou no início da virada do século XIX, a Corsaro, um cientista americano, que aparece um século depois, essas conceções conflitantes de socialização infantil lembram-nos que as conceções teóricas estão inscritas em tempos e espaços diferentes. Mas essas conceções ainda são uma questão de disputa entre diferentes visões da infância na sociologia. 0 que as crianças são capazes de fazer (ou não) e quais são as práticas "boas" ou "adaptadas" dos adultos em relação às crianças são sempre questão de críticas, justificativas e testes, como é o caso na vida quotidiana (Garnier, 2014).

O que está em jogo é como pensar as diferenças e equivalências entre crianças e adultos. Entre outros sociólogos, Lee defendeu uma "sociologia imatura" que não considera a idade adulta como uma identidade definitiva e estável, mas como uma incompletude como a infância. Se a idade adulta não é mais o objetivo teleológico da vida das crianças, então a socialização 
deve ser entendida como dependente dos significados subjacentes das categorizações de idade. Nesta perspetiva, estudar a socialização das crianças requer atenção a esses pressupostos antropológicos subjacentes às categorias de idade e ao seu impacto no desenho da investigação.

\section{Socialisation}

Socialisation is a key concept in the sociology of childhood and more broadly a cornerstone of sociology since its very beginning. This concept has a long history, with many different theoretical conceptions of what to be " social » means. There are so many definitions that it is impossible to address all of them here. Among them, this paper will focus on two competing visions of the socialisation process. The first one, the so-called "classical" vision, can be traced to the ideas of Emile Durkheim, one of the founders of modern social sciences. The other is based on William Corsaro's recent conception of socialisation as children's interpretative reproduction of adults' worlds. We will analyse how this conflict of visions relies on the question of representations of difference and equality between adults and children. It also sheds light on the importance of studying age classifications underlying sociological theories of socialisation.

In Durkheim's view, children's socialisation is at first a question of authority: "man's nature cannot be itself unless it is disciplined" (Durkheim, 1972, p. 111). Socialization then means becoming fully human, through getting integrated in a society, and more precisely becoming part of the division of labour that characterizes this society. Being socialised is also a condition of becoming oneself, a singular person. The process of becoming part of a society requires integrating the moral rules that the members already share. Socialization is thus a vertical process of cultural transmission, from the old generation to the new one. In this conception what is important is children's becoming, a process that starts with family life and then progresses during schooling that improves the homogeneity of moral behaviour and the feeling of a national citizenship, and is later achieved in the world of labour. In this traditional conception of socialisation children are considered as becoming and not yet full members of social life. In Durkheim's view, children are interested in growing-up, imitating adults in order to gain their prestigious status instead of only being dominated. Adults seem to be so powerful that Durkheim warns them not to confuse abuse of power or violence with the legitimate authority over children that society has delegated to them. 
Today, even if they differ from Durkheim's social theory, many sociologists rely on a kind of ontology of social structure that children have to internalize. Depending on the research, the pre-existing social groups may be different in terms of gender, social classes, professional or leisure groups, etc. But in each case, socialisation means to be at first outside of these groups and progressively integrate the values, norms, principles of perception and action that are shared by their members as "natural" ways of being and behaving. Socialisation is thus naturalized in children's bodies.

On the other hand, Corsaro's conception of socialisation relies on the importance of interactions between children and on the importance of children's peer local cultures. This conception emphasises "children's desire to achieve autonomy from the rules and authority of adult caretakers and to gain control over their lives" (Corsaro 2011, p. 166), even if they are still affected by adults. The study of young children's social participation in peer groups does not only show cooperation, but also conflicts and social differentiation. Children are considered not as future beings, who will be involved in social life, but from their birth as social actors in their daily life. In this perspective, children's socialisation is not defined as a reproduction of the adults' world, where they are "shaped and guided by external forces" (Corsaro, 2011, p. 375). On the contrary, socialisation requires their interpretative competences, their own ways of making sense of their lives. This conception makes room for children's agency and sheds light on the innovative and creative dimensions of their social lives.

From Durkheim, a French sociologist working at the beginning of the turn of the 19th century, to Corsaro, an American scientist a century later, these competing conceptions of children's socialisation remind us that theoretical conceptions are inscribed in different times and spaces. But these conceptions are still a question of dispute between different visions of childhood in sociology. What children are able to do (or not) and what the "good" or "adapted" adults practices are in relation to children, are always subject to critiques, justification and tests as is the case in everyday life (Garnier, 2014).

What is at stake is how to think of the differences and similarities between children and adults. Among other sociologists, Lee pleaded for an "immature sociology" that does not consider adulthood as a final and stable identity, but as incompleteness like childhood. If adulthood is no longer the teleological aim of a child's life, then socialisation must be understood as depending on underlying meanings of age categorisations. In this 
perspective, studying children's socialisation requires paying attention to these anthropological assumptions underlying categories of age and their impact on the design of the research.

\section{Referências / References}

Corsaro, W. A. (2011). The Sociology of Childhood (third edition). New York: Sage.

Durkheim, E. (1972). Selected writings (edited, translated, introduced by A. Giddens). Bristol: Cambridge University Press (lessons on moral education, 1902-1903).

Garnier, P. (2014). Childhood as a Question of Critiques and Justifications: Insight into Boltanski's Sociology, Childhood, 21(4), 447-460. 